\title{
Structure of fish communities of French Polynesian coral reefs. II. Temporal scales
}

\author{
René Galzin \\ École Pratique des Hautes Études, Laboratoire de Biologie Marine et Malacologie, 55 Rue de Bufíon, F-75005 Paris, France \\ and
}

Antenne Museum/EPHE, Centre de l'Environnement de Moorea, BP 1013, Moorea, Polynesie Française

\begin{abstract}
Patterns of fish distribution in the northwestern part of Moorea (French Polynesia) were studied at several temporal scales: within a day, within a month, among seasons and between years. Within a day there were diurnal, nocturnal and crepuscular communities and these were probably related to diel variation in the feeding activities of fishes. The within-month study suggested the existence of a $28 \mathrm{~d}$ rhythm where fish abundance was the inverse of species richness. There were seasonal variations at 3 different reefs but they were not the same at each reef (fringing reef, barrier reef and outer slope). Significant differences in community structure were found between 1976 and 1983 at 2 reefs: there was an increase in herbivores and carnivorous fishes that feed among algal turf. These changes were largely explained by a decrease in live coral cover and an increase in algae over the 8 yr period.
\end{abstract}

\section{INTRODUCTION}

In the companion article (Galzin 1987) it was shown that fish on French Polynesian coral reefs are not spatially homogeneous. There was variation along a single transect across the reef, among transects on one island and, at a depth of $12 \mathrm{~m}$, there was variation among islands. Factors such as size of the reef (Sale \& Douglas 1984), hydrology (Leis 1982, 1986), location and geomorphology of reefs (Williams 1982, Williams \& Hatcher 1983, Russ 1984) and percentage cover of live coral (Luckhurst \& Luckhurst 1978a, Bell \& Galzin 1984, Bell et al. 1985, Bouchon-Navaro et al. 1985) have been used to explain such spatial heterogenity.

From work done on Australian reefs (Russell et al. 1977, Talbot et al. 1978, Sale 1979, Williams \& Sale 1981, Doherty 1983, Leis \& Goldman 1983, Williams 1983), it is now clear that temporal variation in rates of settlement and recruitment are very important in explaining these variations. Internal cycles (day and night, lunar, seasonal, etc.) can also be used to explain temporal changes in reef fish communities (Kock 1982, Molina 1983, Galzin 1985).

This article describes temporal variations in the fish community of the northwestern part of the island of Moorea. Four temporal scales were examined: (1) within a day with sampling every $2 \mathrm{~h}$ for a period of
$24 \mathrm{~h}_{i}$ (2) within months with sampling every day for a period of $36 \mathrm{~d}$; (3) within years with sampling every month for a period of $15 \mathrm{mo}$ and (4) among years with comparison of results obtained in this area between 1976 and 1983.

\section{MATERIAL AND METHODS}

This work was done in the Tiahura area (Galzin \& Pointier 1985) on the northwestern part of Moorea Island $\left(17^{\circ} 30^{\prime} \mathrm{S}, 149^{\circ} 50^{\prime} \mathrm{W}\right.$ ) (see Fig. 1 in companion article, p. 130). I established 3 permanent transects $(50 \mathrm{~m}$ long, $2 \mathrm{~m}$ wide) on the fringing reef near the channel, on the barrier reef $150 \mathrm{~m}$ away from the crest, and on the outer slope at $12 \mathrm{~m}$ depth (Fig. 1 in this article).

For each transect, the number of species of fish and the number of individuals of each species were counted during 4 censuses every month (on the same day of the lunar cycle and between 1000 and $1200 \mathrm{~h}$ ) for $15 \mathrm{mo}$. In a single day, on the barrier reef transect, fish were counted 4 times every $2 \mathrm{~h}$ for $24 \mathrm{~h}$. At night, the fish were counted along the transect by a swimmer with an underwater light. In the same transect on the barrier reef, fish were also counted 4 times every day (between 1000 and $1200 \mathrm{~h}$ ) for $36 \mathrm{~d}$. In 1976 and 1983, I counted fishes on five $1 \mathrm{~m}$ wide transects placed randomly each 


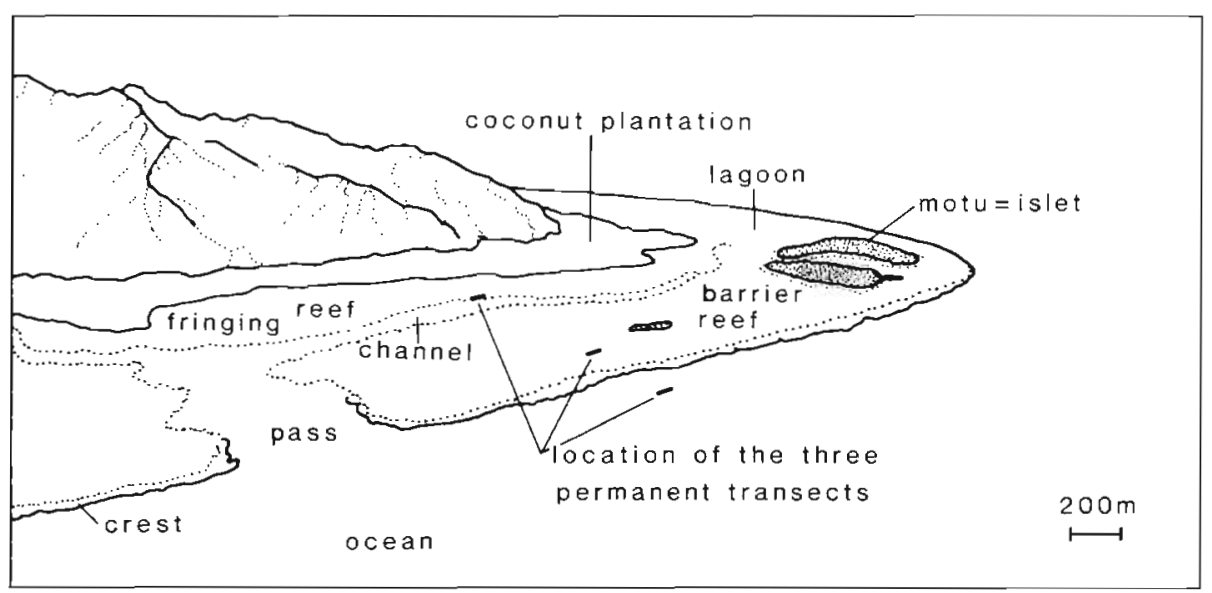

Fig. 1. Aerial view of the northwestern part of Moorea Island with the location of the 3 permanent transects and the geomorphological zonation of the transect of Tiahura

time, from the beach to the channel on the fringing reef and from the channel to the crest of the barrier reef (Table 1).

The resuits obtained were analysed by chronological clustering (Legendre et al. 1985) for the first 2 studies (day/night and seasonal cycles) and by Fourier (1822) analysis for the lunar cycle. The abundances from 1976 and 1983 were compared using ANOVA (Winer 1971).

To study differences in abundance between the same days of a lunar cycle, and the same months for 1982 and 1983, I used the 'coefficient of annual variability' (Wolda 1978). For one species in a given area, the change in abundance from one year to the next is expressed by the ratio (R) of the numbers of individuals in the $2 \mathrm{yr}(\mathrm{R}=\mathrm{N} 1 / \mathrm{N} 2$, or $\log \mathrm{R}=\log \mathrm{N} 2-\log \mathrm{N} 1)$, where $R$ is the net reproductive rate (Andrewartha \& Birch 1954) or the gradation coefficient (Benedek 1970). The mean of this variable calculated for an entire set of species estimates the average change in the group of species as a whole. The variance of $\log R$ was called annual variability (AV).

The present work on temporal variations, the companion article on spatial scales (Galzin 1987) and another work on fisheries yield were all part of a study of communities of coral reef fish in French Polynesia. Logistic constraints on the whole programme limited the design of sampling to that described here.

\section{RESULTS}

\section{Day and night cycle}

Both the principal coordinate analysis and the dendrogram (Fig. 2), derived from the similarity matrix of presence/absence data, divide the fish community

Table 1. Sampling design

\begin{tabular}{|c|c|c|c|c|}
\hline & \multicolumn{3}{|c|}{ Permanent transect (see location in Fig. 1) } & \multirow[t]{2}{*}{ Fringing and barrier reet } \\
\hline & Fringing reef & Barrier reef & Outer slope & \\
\hline Day and night study & - & $\begin{array}{l}\text { Sampling (16 Aug 1983) } \\
\text { every } 2 \mathrm{~h} \text { for } 24 \mathrm{~h}\end{array}$ & - & - \\
\hline Lunar study & - & $\begin{array}{l}\text { Sampling every day be- } \\
\text { tween } 1000 \text { and } 1200 \mathrm{~h} \\
\text { for } 36 \mathrm{~d} \text {, from } 3 \text { May to } \\
7 \text { Jun } 1983\end{array}$ & - & - \\
\hline Seasonal study & $\begin{array}{l}\text { Sampling every month } \\
\text { between } 1000 \text { and } \\
1200 \mathrm{~h} \text { on the same day } \\
\text { of the lunar cycle, for } 15 \\
\text { mo, from Aug } 1982 \text { to } \\
\text { Oct } 1983\end{array}$ & $\begin{array}{l}\text { Sampling every month } \\
\text { between } 1000 \text { and } \\
1200 \text { h on the same day } \\
\text { of the lunar cycle, for } 15 \\
\text { mo, from Aug } 1982 \text { to } \\
\text { Oct } 1983\end{array}$ & $\begin{array}{l}\text { Sampling every month } \\
\text { between } 1000 \text { and } \\
1200 \mathrm{~h} \text { on the same day } \\
\text { of the lunar cycle, for } 15 \\
\text { mo, from Aug } 1982 \text { to } \\
\text { Oct } 1983\end{array}$ & - \\
\hline Long term study & - & - & - & $\begin{array}{l}\text { Sampling of } 5 \text { random } \\
\text { transects perpendicular } \\
\text { to the beach in Jul } 1976 \\
\text { and Aug } 1983\end{array}$ \\
\hline
\end{tabular}



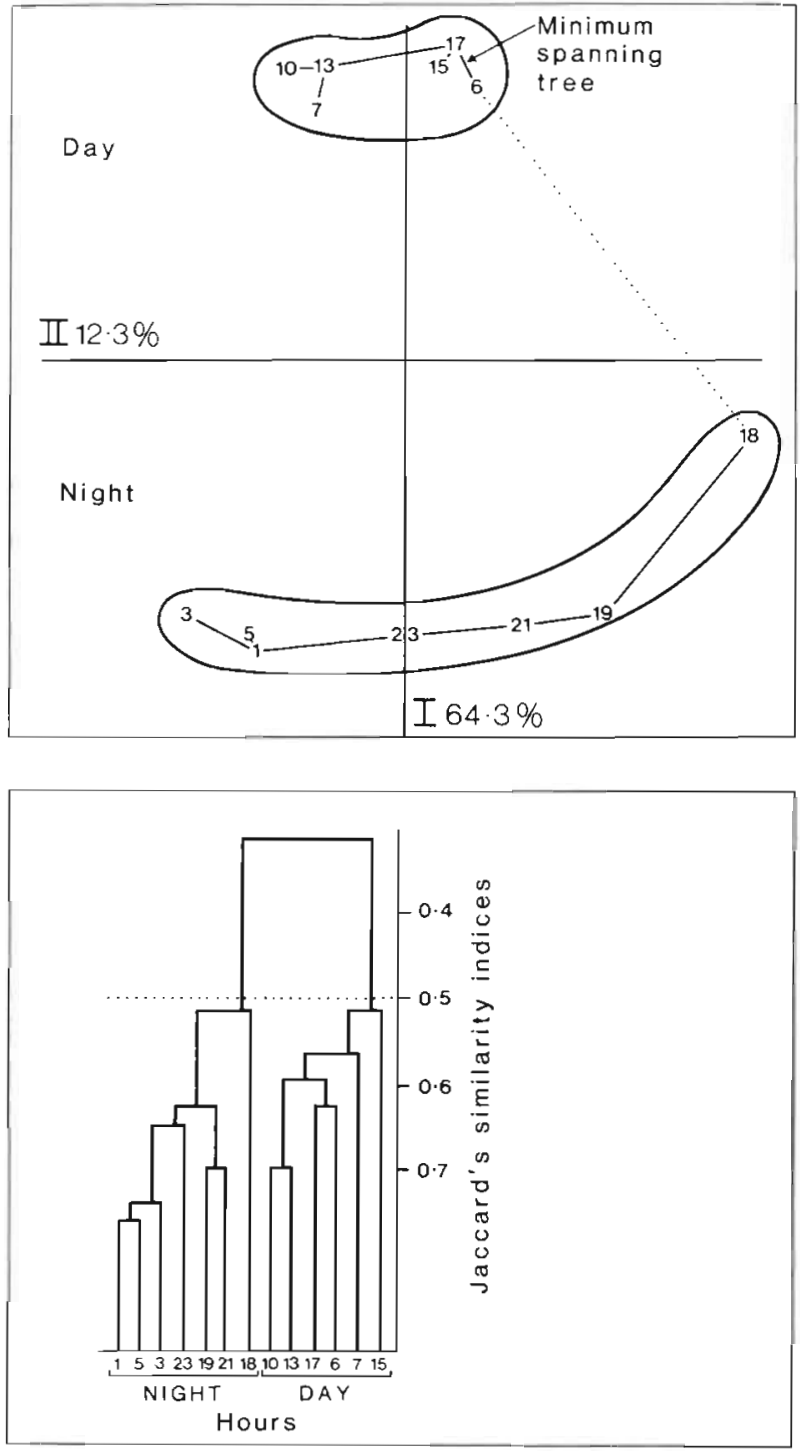

Fig. 2. Plots from the principal coordinates analysis and the dendrogram from the diel study of the coral reef fish commun. ity on the barrier reef of Moorea. Numbers refer to the hour at which samples were taken

into day and night components. The ordination extracted $64 \%$ of the variance of the data on the first vector of the analysis.

Using chronological clustering, 3 communities of fishes were evident on the basis of changes in the number of species during a $24 \mathrm{~h}$ period (Fig. 3): the night community, the day community and the crepuscular community. Changes in the numbers of individuals resulted in 4 communities being recognized: the beginning and end of night communities, and the beginning and end of day communities. The transition between the day and night communities was more gradual when considering the number of species (2h between 0500 and $0700 \mathrm{~h}$, and between 1700 and

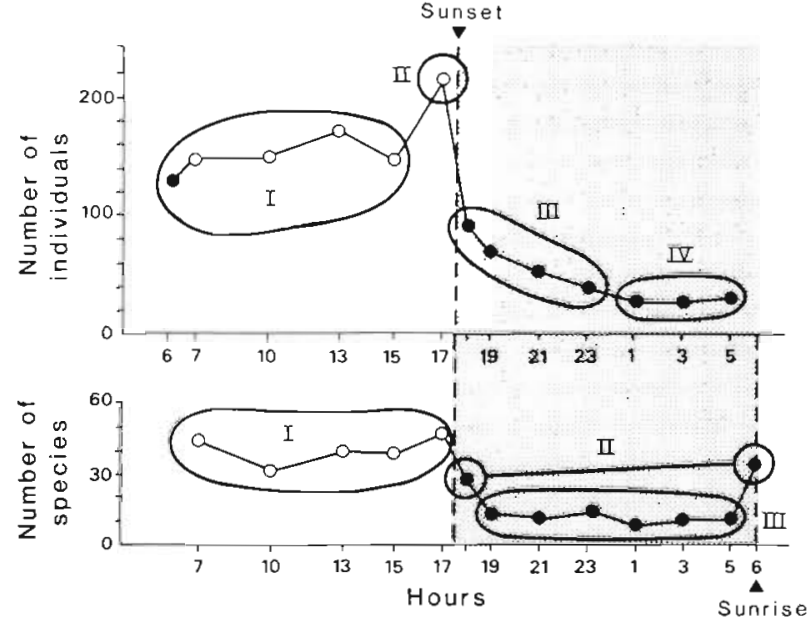

Fig. 3. Changes in number of individuals and number of species during $24 \mathrm{~h}$ on the $100 \mathrm{~m}^{2}$ transect at the barrier reef, northwestern Moorea Island. Three communities of fishes were present on the basis of changes in the number of species, 4 in the number of individuals

$1900 \mathrm{~h}$ ) than for the number of individuals (1 h between 0500 and $0600 \mathrm{~h}$, and between 1700 and $1800 \mathrm{~h})$.

The 80 species of fish identified during this study could be placed into 3 groups (Fig. 4): (1) the nocturnal
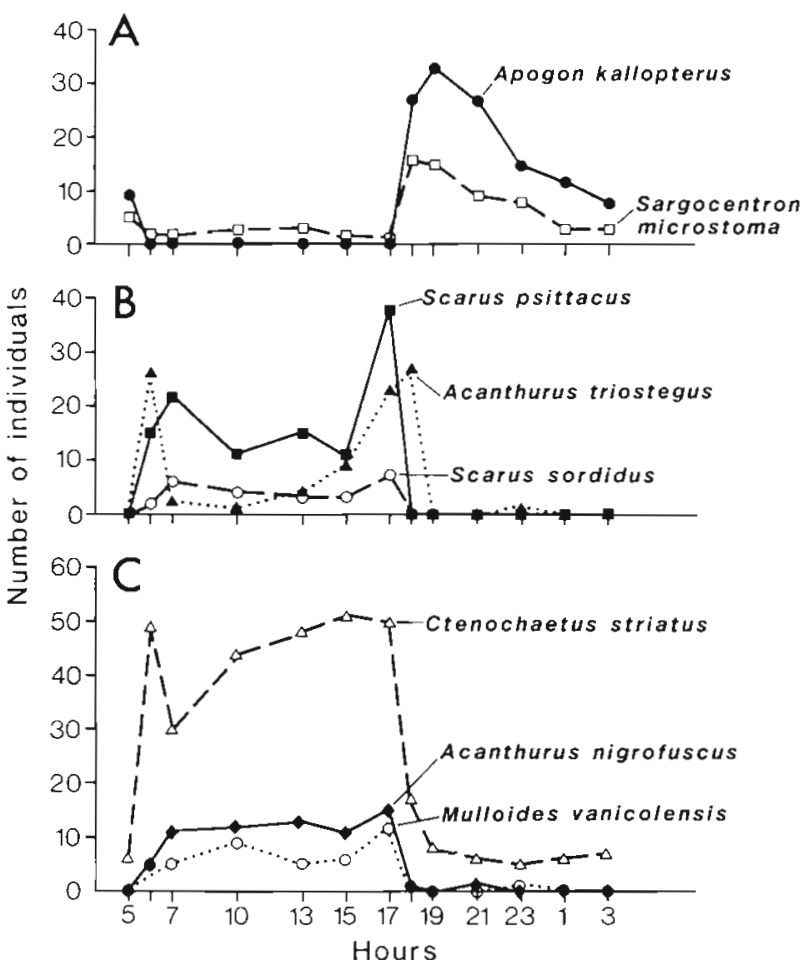

Fig. 4. Changes in the number of individuals of some species during the 24 h study. A: nocturnal carnivorous fish; B: diurnal schooling fish; $C$ : diurnal non-schooling fish 
carnivorous species (Apogonidae, Holocentridae) abundant at the beginning of the night and in very low abundance during the day; (2) the diurnal schooling species which were most abundant on the transect at the beginning and end of each day; (3) the diurnal nonschooling fishes which were abundant throughout the day, but were in low abundance or absent at night.

\section{Lunar cycle}

Of the 91 species observed during the $36 \mathrm{~d}$ of sampling, only 25 species ( $27 \%$ ) were always present. The number of species (Fig. 5) varied between 44 and 57 species whilst the number of individuals on the transect varied between 149 and 290 (1.5 to 2.9 ind $\mathrm{m}^{-2}$ ).

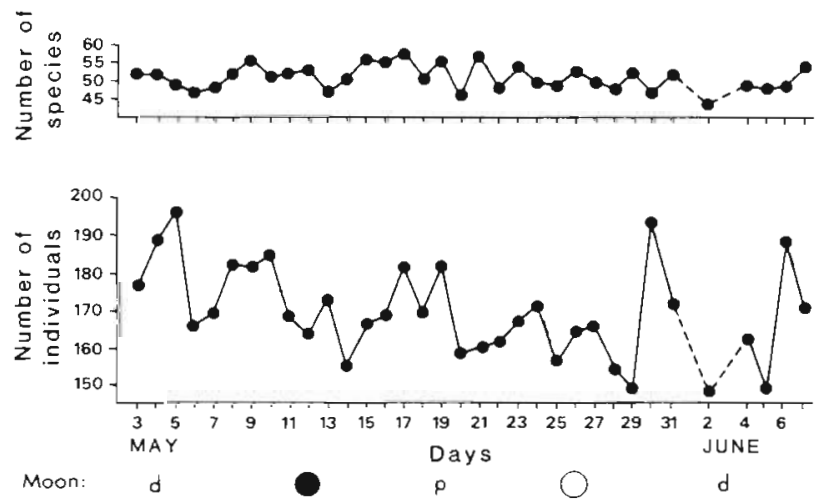

Fig. 5. Changes in the number of individuals and number of species during $36 \mathrm{~d}$ on the $100 \mathrm{~m}^{2}$ transect on northwestern Moorea Island
The Schuster's periodogram (Fourier's [1822] analysis) showed that 30.7 and $37.5 \%$ of the variance of the series could be explained by a periodicity of $28 \mathrm{~d}$ and $14 \mathrm{~d}$, respectively. The number of individuals increased between the last quarter and the new moon and decreased during the first quarter and the full moon. The same periodicity in the abundance of the fishes inside the lagoon in relation to the lunar cycle is well known to Tahitian fishermen (Galzin 1986).

For the 25 species of fish permanently occurring on the transect, the monthly variability coefficient for 5 different days (last quarter $-1,+1,+2,+3$ and +4 d) of the lunar cycle in May and June 1982 was very small (between 0.008 and 0.088). Thus, there was little variation in abundance for these species between 2 successive months.

\section{Seasonal variation}

From the three $100 \mathrm{~m}^{2}$ transects on the fringing reef, the barrier reef, and the outer slope, the variation in the number of species, the number of individuals and Shannon's equitability index (Table 2) were calculated. The number of individuals was smallest on the barrier reef $\left(1.5\right.$ ind $\left.\mathrm{m}^{-2}\right)$. In contrast, the fringing reef transect had densities of 2.7 ind $\mathrm{m}^{-2}$ and, on the outer slope, there were 5.4 ind $\mathrm{m}^{-2}$. The increase in diversity between August and May was similar for the barrier reef and outer slope transects. For the fringing reef, the diversity decreased from August to March and then increased.

On the fringing reef, 25 of the 80 observed species were present during each of the 15 mo sampled. On the

Table 2. Changes in number of species, number of individuals and Shannon's equitability index in the 3 permanent transects of the northwestern part of Moorea Island. Observations took place between 1000 and $1200 \mathrm{~h}$ on the same day of the lunar cycle every month

\begin{tabular}{|c|c|c|c|c|c|c|c|c|c|c|c|c|c|c|c|}
\hline & \multicolumn{5}{|c|}{1982} & \multicolumn{10}{|c|}{1983} \\
\hline & $A$ & $\mathrm{~S}$ & 0 & $\mathrm{~N}$ & $\mathrm{D}$ & J & $\mathrm{F}$ & $M$ & A & $M$ & $\mathrm{~J}$ & j & A & S & 0 \\
\hline \multicolumn{16}{|l|}{ Fringing reef } \\
\hline No. of species & 40 & 36 & 36 & 48 & 43 & 49 & 45 & 48 & 40 & 43 & 48 & 41 & 44 & 43 & 40 \\
\hline No. of individuals & 255 & 273 & 250 & 324 & 267 & 276 & 260 & 253 & 206 & 245 & 256 & 250 & 215 & 224 & 260 \\
\hline $\begin{array}{l}\text { Shannon's equita- } \\
\text { bility }\end{array}$ & 0.63 & 0.62 & 0.59 & 0.62 & 0.58 & 0.57 & 0.55 & 0.51 & 0.57 & 0.59 & 0.59 & 0.60 & 0.65 & 0.64 & 0.57 \\
\hline \multicolumn{16}{|l|}{ Barrier reef } \\
\hline No. of species & 33 & 37 & 41 & 44 & 41 & 49 & 50 & 49 & 53 & 55 & 45 & 41 & 36 & 37 & 40 \\
\hline No. of individuals & 97 & 111 & 139 & 144 & 128 & 148 & 155 & 180 & 195 & 161 & 148 & 136 & 147 & 130 & 161 \\
\hline $\begin{array}{l}\text { Shannon's equita- } \\
\text { bility }\end{array}$ & 0.77 & 0.81 & 0.80 & 0.81 & 0.84 & 0.82 & 0.79 & 0.77 & 0.80 & 0.80 & 0.75 & 0.77 & 0.77 & 0.80 & 0.79 \\
\hline \multicolumn{16}{|l|}{ Outer slope } \\
\hline No. of species & 45 & 55 & 58 & 60 & - & 56 & 60 & 62 & 60 & 69 & 62 & 56 & 58 & 62 & 60 \\
\hline No. of individuals & 423 & 545 & 518 & 532 & - & 485 & 428 & 470 & 538 & 552 & 530 & 648 & 473 & 632 & 535 \\
\hline $\begin{array}{l}\text { Shannon's equita- } \\
\text { bility }\end{array}$ & 0.71 & 0.71 & 0.74 & 0.74 & - & 0.78 & 0.75 & 0.76 & 0.76 & 0.77 & 0.72 & 0.73 & 0.72 & 0.72 & 0.74 \\
\hline
\end{tabular}


barrier reef, 21 of the 90 species sampled during the 15 mo were always present. Of the 104 species sampled on the outer slope, 41 were always present during the 14 mo of the study (sampling in December 1982 was not possible). The number of species varied between 45 in August and 69 in May.

For the outer slope, the similarity of the results obtained by chronological clustering on the presence/ absence data and the quantitative data (Fig. 6), gave 3 major periods of temporal changes. Only one intermediate season was found in June-July, where the presence/absence results did not correspond with the quantitative results. For the barrier reef, there were 2 intermediate seasons, one in May-June and the other in October. There were 3 for the fringing reef: April, July and November. For the barrier reef and the fringing reef, these seasonal variations were a result of variations in populations of all species. For the outer slope, the overall variability was mainly due to large variation in populations of a few zooplanktivorous species: e.g. Chromis vanderbilti, Chromis xanthura, Dascyllus trimaculatus, Anthias pascalus (Fig. 7).

\section{Long-term changes}

The coefficient of annual variability for 1982 and 1983 for the months of August, September and October was 0.13 , indicating relative constancy of the coral reef fish community between these 2 years. However, this relative constancy was not apparent over a longer time period. Between 1976 and 1983, the mean number of fishes increased from 367 to 636 for the fringing reef and from 673 to 1285 for the barrier reef (Table 3). For the 26 families and 2 species counted, only 6 showed significatively different results between 1976 and 1983. The number of Labridae, Scaridae and Ctenochaetus striatus increased for both the fringing and the barrier reef. I noted an increased in Stegastes nigricans and Gobiidae for the fringing reef and an increase of the Balistidae for the barrier reef. Only the number of Zanclidae decreased significatively between 1976 and 1983 on the fringing reef.

\section{DISCUSSION}

The structure of the fish community at Tiahura varied significantly on a daily, monthly, seasonal and annual basis. Within a day, 3 recognizable communities (diurnal, nocturnal and crepuscular) were identified from the qualitative data and 4 communities ( 2 diurnal and 2 nocturnal) from the quantitative data. The main finding from the month-long study was an apparent inverse relation between changes in abundance and species richness. The abundance of fish appears to be maximal during the period of the last quarter and full moon. Seasonal variations showed 3 periods of temporal change between different communities. Generally, these periods corresponded to wet season, dry season and intermediate season. Significant differences in community structure were found between 1976 and 1983. Replicate data, such as several permanent transects in each habitat and several scales of time, should be collected in order to verify the patterns suggested here.

Distinct crepuscular and nocturnal communities were found in the present study. Hobson (1974) in Hawaii and Harmelin-Vivien (1979) in Madagascar discussed, but presented no evidence for, crepuscular communities of coral reef fishes. Colton \& Alevizon (1981) examined within-day variations in abundance of reef fishes in the Bahamas, but did not mention a cerpuscular community. Within-day variation in numbers of individuals and number of species within the transect were possibly related to diel variation in the feeding activities of fishes (Luckhurst \& Luckhurst $1978 b, c)$. In Moorea, $37 \%$ of the fish were nocturnal species, which is almost the same as the result obtained for Madagascar reefs $(36 \%)$ by Harmelin-Vivien (1979). The difference observed between the 4 qualitative and the 3 quantitative communities in this study could be explained by the rapid appearance of nocturnal carnivorous fishes (Holocentridae, Apogonidae) moving into the water column to feed on nocturnally emergent prey such as zooplankton, benthic crustaceans and polychaetes (Hobson \& Chess 1978). One way to test this hypothesis would be to sample fish and
Fig. 6. Representation of fish communities derived from chronological clustering of monthly data at 3 habitats. Communities derived from presence/absence data (Jaccard's coefficient) are shown within the inner circles, whereas those derived from quantitative data (Steinhaus' coefficient) are shown within the outer circles. Encircled months indicate where both analyses give similar results. These monthly groupings depict seasonal fish communities fish corresponding to wet, dry and intermediate seasons

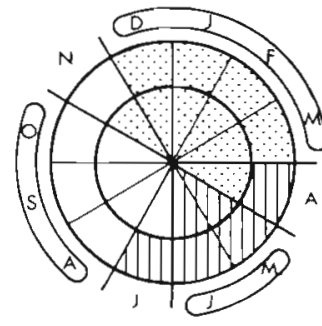

Fringing reef

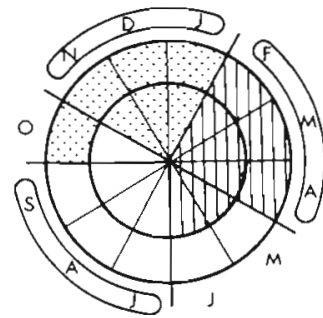

Barrier reef

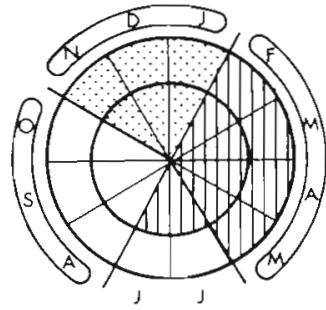

Outer slope 


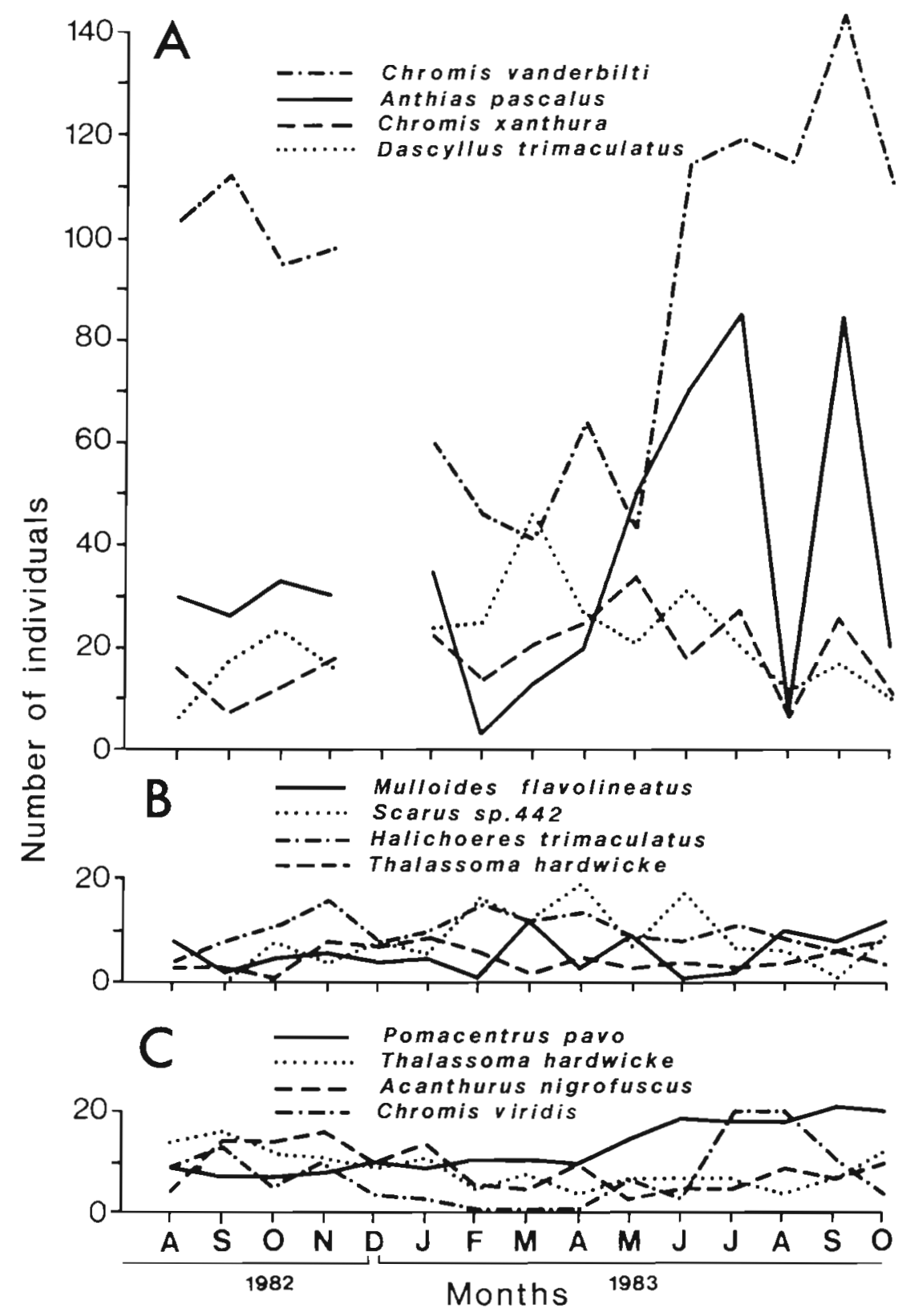

Fig. 7. Seasonal changes in the number of individuals for some abundant fish occurring permanently on the 3 transects at Tiahura during 15 mo. A: outer slope; B: barrier reef; $C$ : fringing reef zooplankton simultaneously to establish whether the appearance of the nocturnal fishes is synchronized with the emergence of the endofauna. The peak abundance of schooling diurnal species in the transect may also relate to feeding activities. I suggest that these species school to feed during the day and disperse at the end of the day. The peak abundances of individuals on the transect at the beginning and end of the day represent dispersed, non-feeding, individuals prior to early morning school formation, and these fish after dispersal of feeding school, after dark.

Data were collected over too short a period to determine a precise lunar cycle. Better replicated surveys covering several lunar months are needed to determine the validity of my results and to identify the cause of such temporal variation. From the work of Johannes (1978), Lobel (1978), Pressley (1980) and Goldman et al. (1983) it seems that the factors responsible for a lunar cycle in fish reproduction include tide, light or variations in zooplankton.

Seasonal variations in the structure of fish communities on the fringing reef were the result of synchronised variation in many species. Seasonal variation on the outer slope, however, was due to large variations in densities of only a few species. I do not know the cause of variation in fish abundance on the 
Table 3. Means of number of fish counted in 5 transects on the fringing reef and the barrier reef of Moorea in 1976 and 1983 for 26 families and 2 species of fish. Significantly different results between 1976 and 1983 are indicated by: $p<0.05 ; \cdots p<0.01$; $\cdots p<0.001$

\begin{tabular}{|c|c|c|c|c|c|c|}
\hline \multirow[t]{2}{*}{ Species or family } & \multicolumn{3}{|c|}{ Fringing reef } & \multicolumn{3}{|c|}{ Barrier reef } \\
\hline & 1976 & 1983 & $\mathrm{p}$ & 1976 & 1983 & $\mathrm{p}$ \\
\hline Muraenidae & 1 & 0 & & 0 & 0 & \\
\hline Synodontidae & 0 & 0 & & 3 & 0 & \\
\hline Belonidae & 1 & 0 & & 11 & 6 & \\
\hline Holocentridae & 5 & 1 & & 6 & 8 & \\
\hline Scorpaenidae & 1 & 0 & & 0 & 0 & \\
\hline Serranidae & 2 & 0 & & 4 & 6 & \\
\hline Apogonidae & 0 & 0 & & 0 & 3 & \\
\hline Carangidae & 1 & 0 & & 1 & 1 & \\
\hline Lutjanidae & 0 & 0 & & 3 & 2 & \\
\hline Mullidae & 18 & 5 & & 21 & 12 & \\
\hline Chaetodontidae & 22 & 18 & & 57 & 58 & \\
\hline Pomacanthidae & 6 & 4 & & 22 & 13 & \\
\hline Pomacentridae & 40 & 22 & & 76 & 75 & \\
\hline Stegastes nigricans & 86 & 131 & $\cdots$ & 32 & 38 & \\
\hline Cirrhitidae & 0 & 0 & & 2 & 0 & \\
\hline Mugilidae & 39 & 37 & & 2 & 18 & \\
\hline Labridae & 50 & 134 & $\cdots$ & 81 & 208 & $\cdots$ \\
\hline Scaridae & 30 & 128 & $\cdots$ & 34 & 183 & $\cdots$ \\
\hline Blenniidae & 2 & 0 & & 1 & 0 & \\
\hline Gobiidae & 2 & 14 & $\cdots$ & 2 & 6 & \\
\hline Acanthuridae & 8 & 16 & & 28 & 97 & \\
\hline Ctenochaetus striatus & 43 & 118 & $\cdots$ & 266 & 528 & $\cdots$ \\
\hline Zanclidae & 3 & 1 & $\cdot$ & 2 & 3 & \\
\hline Siganidae & 1 & 1 & & 2 & 2 & \\
\hline Pleuronectidae & 1 & 0 & & 2 & 0 & \\
\hline Balistidae & 2 & 2 & & 5 & 10 & . \\
\hline Ostraciontidae & 1 & 3 & & 3 & 2 & \\
\hline Tetraodontidae & 2 & 1 & & 7 & 6 & \\
\hline Total no. of individuals & 367 & 636 & & 673 & 1285 & \\
\hline
\end{tabular}

fringing reef. I suggest several possibilities: temperature and salinity of the water (Ricard 1977), nutrients in the water (B. Delesalle pers. comm.), flora (C. Payri pers. comm.) and fauna (Lefevre 1986). The large variations in abundance of a few species on the outer slope may be the result of interseasonal fluctuations in recruitment (reviewed in Munro \& Williams 1985). For each part of the reef, but particularly on the outer slope, the possibility remains that inadequate sampling (i.e. only one transect for a one-time-point study) could account for the large fluctuations in numbers of fish. Large variations in abundance which could be caused by recruitment were not taken into account during this study (because sampling involved collection of a number of fish without any information on size). The seasonal variations may also be due in part to seasonal movements of fishes between different sites within the reef. The concomitant increase/decrease of the number of fishes between the fringing and the barrier reef (Fig. 8) could be explained by reproductive movements (adults, settlement of the larvae) inside the reef. For

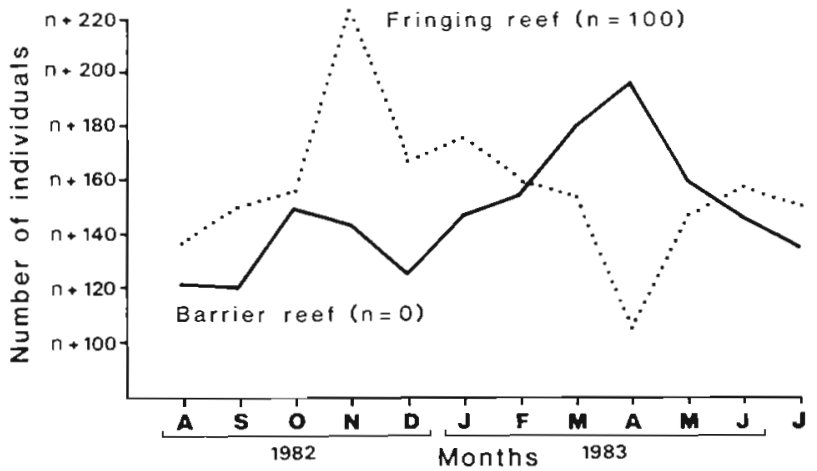

Fig. 8. Seasonal variation of the total number of individuals on 2 permanent transects $\left(100 \mathrm{~m}^{2}\right)$ at the fringing reef and the barrier reef, northwestern Moorea Island

one dominant species, Ctenochaetus striatus (Fig. 9), the size distribution is not homogenous on the reef. The question to resolve is whether the young fishes found inside the first stations of the reef near the shore will 


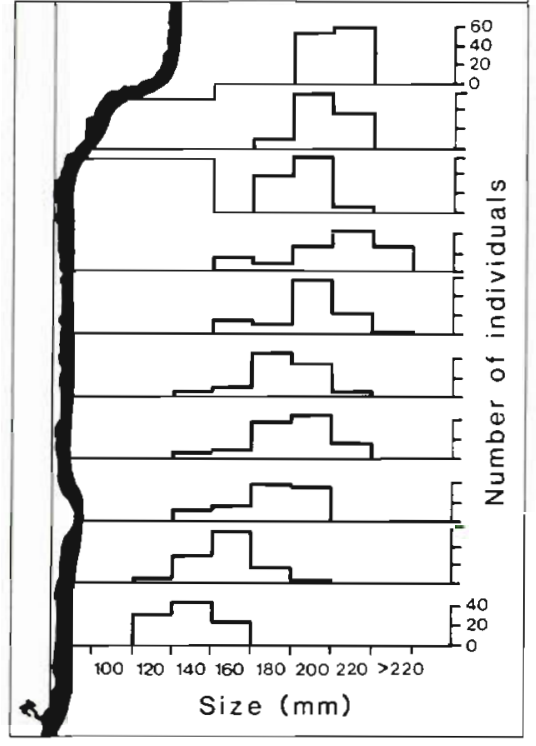

Fig. 9. Ctenochaetus striatus. Size distribution (total length) along the Tiahura transect

grow up in this same area or will move later to other parts of the reef.

Relatively little interannual variation in community structure was found between 1982 and 1983 but significant variation was found between 1976 and 1983. The latter is likely to be due to significant environmental variations over this period. The percentage of live coral cover in the study area was reduced by $50 \%$ between 1979 and 1982. No satisfactory explanation has yet been found for this decrease in live coral cover which could have many causes. Bouchon-Navaro et al. (1985) demonstrated a clear relation between environmental changes and the structure of the butterflyfish assemblage at the site. The abundance of obligate coral feeding species decreased significantly with the decreased cover of live coral while the abundance of Chaetodon citrinellus, a non-coral-feeder, increased. I did not find any significant variation in abundance of butterflyfishes. There may have been a decrease in abundance of obligate coral-feeders and an increase in abundance of non-coral-feeders. The results of the present study indicate a significant increase in the number of individuals of the herbivorous fishes (Scaridae, Ctenochaetus striatus) and a significant increase in the number of individuals of Stegastes nigricans, Labridae and Balistidae. The omnivorous $S$. nigricans, and some of the carnivorous species of labrids and balists, feed among the algal turf, which increased when live coral cover decreased. There was also a significant decrease of the carnivorous fish Zanclidae. I cannot explain the significant increase of the Gobiidae. The diversity of this family in French Polynesia is too high (34 genera and 60 species) to draw meaningful conclusions, i.e. there is much scope for changes in abundance of some species to cancel changes in others.

Williams (1986) studied the temporal variation in the structure of reef slope fish communities after an Acanthaster planci infestation on the Great Barrier Reef. He concluded that 'Longer-term study will be required to determine whether or not $A$. planci infestations have long-term effects on the adult densities of fishes other than the scleractinian-feeding chaetodontids.' This study demonstrates that a decrease in live coral cover over an 8 yr period has a long-term effect on the adult densities of herbivorous fish (Scaridae, Ctenochaetus striatus) as well as browsers on algal turf (Stegastes nigricans, Balistidae, Labridae). This suggests that damage to coral reefs, with a decrease of the live coral cover, will not only affect abundances of obligate coral feeders but may also affect abundances of other families.

Clearly, the activity rhythms and behaviors of species contribute to the organisation of fish communities on coral reefs. On the other hand, catastrophic events (Acanthaster planci attacks, hurricanes, drop in water level within lagoons, human disturbances, etc.) also caused temporal variation on these communities. To judge ecological stability or persistence (Connell \& Sousa 1983) of coral reef fish communities, we need to pursue research on factors affecting equilibrium point(s), resistance, amplitude and elasticity of fish communities. The work presented here, and that of Galzin (1987) and Galzin \& Legendre (1987), indicate the spatial and temporal scales at which such research should take place in French Polynesia.

Acknowledgements. I thank J. Bell, R. Bradley, L. Kaufman, A. J. Underwood, D. Williams and 3 anonymous reviewers who provided critical discussions and comments on earlier drafts of the manuscript. This work is a contribution to RCP 806 CNR 5.

\section{LITERATURE CITED}

Andrewartha, H. G., Birch, L. C. (1954). The distribution and abundance of animals. Univ. Chicago Press, Chicago

Bell, J. D., Galzin, R. (1984). Influence of live coral cover on coral-reef fish communities. Mar. Ecol. Prog. Ser 15: 265-274

Bell, J. D., Harmelin-Vivien, M., Galzin, R. (1985). Large scale spatial variation in abundance of butterflyfishes (Chaetodontidae) on Polynesian reefs. Proc. 5th. Int. Coral Reef Cong. Tahiti 5: 421-426

Benedek, P. (1970). The Hungarian countrywide light-trap network in the service of plant protecting forecasting. Europe Mediterranean Plant Protec. Organ. Pub. Ass. 57: 163-167

Bouchon-Navaro, Y., Bouchon, C., Harmelin-Vivien, M. (1985). Impact of coral degradation on a chaetodontid fish assemblage (Moorea, French Polynesia). Proc. 5th Int. Coral Reef Cong. Tahiti 5: 427-432 
Colton, D.E., Alevizon, S. W. (1981). Diurnal variabnility in a fish assemblage of a Bahamian coral reef. Environ. Biol Fish. $6(3-4)$ : 378-909

Connell, J. H., Sousa, W. P. (1983). On the evidence needed to judge ecological stability or persistence. Am. Nat. $121(6)$ : $789-824$

Doherty, P. (1983). Recruitment surveys of coral reef fishes as tools for science and management. In: Baker, J. T., Carter, R., Sammarco, P. W., Starck, K. (ed.) Proc. Great Barrier Reef. Conf., Townsville, Australia, 29 Aug-5 Sep 1983. James Cook Univ. Press, Townsville, p. 191-196

Fourier, J. (1822). Theorie analytique de la chaleur. In: Darboux, G. (ed.) Oeuvres de Fourier, Tome 1. Gauthier Villars, Paris

Galzin, R. (1985). Ecologie des poissons récifaux de Polynesie française. Thèse de Doctorat ès Sciences, Université des Sciences et Techniques du Languedoc Montpellier

Galzin, R. (1986). Poissons récifaux et pêche polynesienne. Bull. Soc. Etud. Oceaniennes 234 (19-11): 32-41

Galzin, R. (1987). Structure of fish communities of French Polynesian coral reefs. I. Spatial scales. Mar. Ecol. Prog. Ser. 41: 129-136

Galzin, R, Legendre, P. (1987). The fish communities of a coral reef transect. Pacif. Sci. (in press)

Galzin, R., Pointier, J. P. (1985). Moorea Island, Society Archipelago. Proc. 5th. Int Coral Reef Cong. Tahiti 1. 73-101

Goldman, B., Stroud, G., Talbot, F. (1983). Fish eggs and larvae over a coral reef: with habitat, time of day and moon phase. Proc. Inaugural Great Barrier Reef Conf. James Cook Univ. Press, Townsville, p. 203-211

Harmelin-Vivien, M. (1979). Ichtyofaune des récifs coralliens de Tulear (Madagascar): ecologie et relations trophiques. Thèse de Doctorat ès Sciences, Université Aix-Marseille II

Hobson, E. S. (1974). Feeding relationships of Teleostean fishes on coral reefs in Kona, Hawaii. Fish. Bull. U.S. 72 (4): $915-1031$

Hobson, E. S., Chess, J. R. (1978). Trophic relationships among fishes and plankton in the lagoon at Enewetak Atoll, Marshall Islands. Fish. Bull. U. S. 76: 133-153

Johannes, R. E. (1978). Reproductive strategies of coastal marine fishes in the tropics. Environ. Biol. Fish. 3 (1): 65-84

Kock, R. E. (1982). Patterns of abundance variation in reef fishes near an artificial reef at Guam. Environ. Biol. Fish. 7 (2): $121-136$

Lefevre, M. (1986). Variation spatio-temporelle du peuplement zooplanctonique du lagon de l'île de Moorea, Archipel de la Société, Polynesie Française. Thèse de l'Université Paris VI

Legendre, P., Dallot, S., Legendre, L. (1985). Succession of species within a community: chronological clustering, with applications to marine and freshwater zooplankton. Am. Nat. 125: 257-288

Leis, J. M. (1982). Nearshore distributional gradients of larval fish (15 taxa) and planktonic crustaceans (6 taxa) in Hawaii. Mar. Biol. 72: 89-97

Leis, J. M. (1986). Vertical and horizontal distribution of fish larvae near coral reefs at Lizard Island, Great Barrier Reef. Mar. Biol. 90: 505-516

Leis, J. M., Goldman, B. (1983). Studies on the biology of larval fishes in the Lizard Island area, northern Great Barrier Reef. Proc. Inaugural Great Barrier Reef Conf. James Cook Univ. Press, Townsville, p. 221-225
Lobel, P. S. (1978). Diel, lunar and seasonal periodicity in the reproductive behavior of the pomacanthid fish, Centropyge potteri, and some other reef fishes in Hawaii Pacif. Sci. 32 (2): 193-207

Luckhurst, B. E., Luckhurst, K. (1978a). Analysis of the influence of substrate variables on coral reef fishes communities. Mar Biol. 49: 317-323

Luckhurst, B. E., Luckhurst, K. (1978b). Diurnal space utilisation in coral reef fish communities. Mar. Biol. 49: 324-332

Luckhurst, B. E., Luckhurst, K. (1978c). Nocturnal observations of coral reef fishes along depth gradients. Can. J. Zool. 56 (2): 155-158

Molina, M. E. (1983). Seasonal and annual variation of coralreef fishes on the upper reef slope at Guam. M. Sc. thesis, University of Guam

Munro, J. L., Williams, D. McB. (1985). Assessment and management of coral reef fisheries: biological, environmental and socio-economic aspects. Proc. 5th. Int. Coral Reef. Congress, Tahiti 4: 544-578

Pressley, P. H. (1980). Lunar periodicity in the spawning of yellowtail damselfish Microspathodon chrysurus. Environ. Biol. Fish. 5 (2): 153-159

Ricard, M. (1977). Les peuplements de diatomées des lagons de l'Archipel de la Société (Polynesie Française). Rev. Algo. 12 (3): 138-336

Russ, G. R. (1984). The distribution and abundance of herbivorous grazing fishes in the central Great Barrier Reef. I. Levels of variability across the entire continental shelf. Mar Ecol. Prog. Ser 20: 23-34

Russell, B. C., Anderson, G. R. V., Talbot, F. H. (1977). Seasonality and recruitment of coral reef fishes. Aust. J. mar. Freshw. at. Res. 28: 521-528

Sale, P. F. (1979). Recruitment, loss and coexistence in a guild of territorial coral reef fishes. Oecologia (Berl.) 42: 159-179

Sale, P. F., Douglas, W. A. (1984). Temporal variability in the community structure of fish on coral patch reefs and the relation of community structure to reef structure. Ecology 65 (2); 409-4.22

Talbot, F. H., Russell, B. C., Anderson, G. R. V (1978). Coral reef fish communities: unstable, high-diversity systems? Ecol. Monogr. 48: 440-455

Williams, D. McB. (1982). Patterns in the distribution of fish communities across the Central Great Barrier Reef. Coral Reefs 1. 35-43

Williams, D. McB. (1983). Daily, monthly and yearly variability in recruitment of a guild of coral reef fish. Mar. Ecol. Prog. Ser. 10: 231-237

Williams, D. McB. (1986). Temporal variation in the structure of reef slope fish communities (central Great Barrier Reef): short-term effects of Acanthaster planci infestation. Mar. Ecol, Prog. Ser 28: 157-164

Williams, D. McB., Hatcher, A. I. (1983). Structure of fish communities on outer-slopes of inshore, mid-shelf and outer shelf reefs on the Great Barrier Reef. Mar. Ecol. Prog. Ser 10: 239-250

Williams, D. McB., Sale, P. F. (1981). Spatial and temporal patterns of recruitment of juvenile coral reef fishes to coral habitats within One Tree Lagoon, Great Barrier Reef. Mar. Biol. 65: 245-253

Winer, B. (1971). Statistical principles in experimental design. 2nd edn. McGraw-Hill, New York

Wolda, H. (1978). Fluctuations in abundance of tropical insects. Am. Nat. 112: 1017-1045 